\title{
Dephosphorization Kinetics and Reaction Region in Hot Metal during Lime Injection with Oxygen*
}

\author{
By Hitoshi ONO, ,* Tamenori MASUI** and Hisashi MORI***
}

\section{Synopsis}

To improve dephosphorization of hot metal by the lime injection process, it is necessary to clarify the dissolution mechanism of blown-in $\mathrm{CaO}$ in hot metal, the mechanism of dephosphorization reaction and the region where the reaction takes place. For this purpose, a single-crystal lime lump immersion test and a lime powder injection test were made. Lime lumps after immersion tests, reaction products adhered to $\mathrm{Al}_{2} \mathrm{O}_{3}$ tubes immersed into hot metal and collected slag samples by steel samples were analyzed by EPMA.

In hot metal, $\mathrm{CaO}$ starts to dissolve due to penetration of $\mathrm{Fe}_{t} \mathrm{O}$ and $\mathrm{Mn}_{t} \mathrm{O}$. Then, the dephosphorization reaction initiates between $\{\mathrm{CaO}$ $\left.\mathrm{Fe}(\mathrm{Mn})_{t} \mathrm{O}\right\}_{l}$ and phosphorus, and the latter is fixed as $\left(\mathrm{CaO}-\mathrm{SiO}_{2}-\right.$ $\left.\mathrm{P}_{2} \mathrm{O}_{5}\right)_{s}$ in the reaction layers. Dephosphorization takes place mainly in the vicinity of the oxygen blowing nozzle.

The slagging rate of solid $\mathrm{CaO}$ decreases with increasing distance between the nozzle and the suspending position of $\mathrm{CaO}$ since carbon in hot metal consumes oxygen. The dephosphorization rate also decreases with increasing distance since $\mathrm{Fe}_{t} \mathrm{O}$ in $\left\{\mathrm{CaO}-\mathrm{Fe}(\mathrm{Mn})_{t} \mathrm{O}\right\}_{l}$ is reduced by carbon.

It is concluded that the increases both in the slagging rate of solid lime and oxygen potential in the bath is necessary to enhance the dephosphorization rate and in this sense, the injection of iron oxide with oxygen is effective.

\section{Introduction}

Lately, the dephosphorization process of hot metal by injection of mixed flux of lime and iron oxide has been developed and adapted in commercial operation, and lime injection with oxygen is also tested at some plants.

The slagging rate of $\mathrm{CaO}$ has a great effect on the slag-metal reaction in the steel making process. For this reason, many fundamental and practical studies $^{1-10)}$ have so far been made on the mechanism of $\mathrm{CaO}$ dissolution into slag and the dissolution rate. In hot metal dephosphorization by lime injection, however, it is not always clear how the injected lime forms slag in hot metal and reacts with phosphorus. In this respect, Haida et al. ${ }^{11)}$ have recently discussed the mechanism of dephosphorization by $\mathrm{CaO} \cdot \mathrm{Fe}_{t} \mathrm{O}$ from the results of hot metal dephosphorization by Q-BOP. The authors have also obtained the information $^{12)}$ that the rate and extent of dephosphorization are substantially improved by injecting a mixed flux of lime and iron oxide with oxygen. Therefore, it might be thought that the lime injected with oxygen into hot metal forms slag rapidly and participate in the dephosphorization reaction. To improve hot metal dephosphorization, however, it is necessary to clarify the process of this reaction.
In view of the above-mentioned statement, an alumina tube and a sampler (see Fig. 2) were firstly immersed into hot metal, through which lime powder was injected with oxygen, and the floating reaction product was allowed to adhere to the tube or enter the sampler in order to examine the reaction process of CaO. Then, a single-crystal lime lump was immersed into hot metal melted in a crucible and oxygen was injected to examine the slagging process of $\mathrm{CaO}$ and the mechanism of dephosphorization. The reason why a lime crystal is used is that a single crystal is suitable to observe the reaction layer without the effect of voids and grainboundaries. Further, alumina tubes, steel samplers and single-crystal lime lumps were immersed into hot metal at various positions in order to know the region where the injected lime reacts.

The dephosphorization mechanism of hot metal and the region where dephosphorization takes place during lime injection with oxygen were discussed on the basis of the results of these experiments.

\section{Experimental Method}

\section{Lime Powder Injection Test}

1. The Methods Used for the Collection of Reaction Products by means of $\mathrm{Al}_{2} \mathrm{O}_{3}$ Tubes and Preparation of Samples

Slag sampling method is shown in Fig. 1. A $\mathrm{MgO}$ crucible was set in a high frequency induction furnace and pig iron having the composition shown in Table 1 weighing 10 kilograms was melted. The experiment was done at $1350^{\circ} \mathrm{C}$. Lime powders were injected at the rate of $7.7 \mathrm{~g} / \mathrm{min}$ for $13 \mathrm{~min}$ with a mixed gas $\left(\mathrm{O}_{2} 4 \mathrm{l} / \mathrm{min}+\mathrm{Ar} 3 \mathrm{l} / \mathrm{min}\right)$ through a copper nozzle provided in the bottom of the crucible. During injection, the floating reaction product (slag) adhered to $\mathrm{Al}_{2} \mathrm{O}_{3}$ tubes which were immersed in the bath at the positions $45 \mathrm{~mm}$ and $90 \mathrm{~mm}$ above the blowing nozzle.

A slag of $30 \mathrm{~mm}$ maximum diameter and about $50 \mathrm{~mm}$ long adhered around $\mathrm{Al}_{2} \mathrm{O}_{3}$ tubes as a result of bottom injection of lime. Lumps of slag sample were embedded in polyester resin which was solidified later. After that, doughnut-shaped specimens of $20 \mathrm{~mm}$ diameter and $10 \mathrm{~mm}$ thick were cut from the position near the end of slag adhered. After grinding with diamond paste, gold vapour deposition was done

* Based on the paper presented to the 104th ISIJ Meeting, September 1982, S966, at Hokkaido University in Sapporo. Manuscript received June 11, 1984; accepted in the final form on September 7, 1984. (C) 1985 ISIJ

** Sakai Technical Research Laboratories, Nippon Steel Corporation, Chikko-Yawatamachi, Sakai 590.

*** R \& D Laboratories-III, Nippon Steel Corporation, Edamitsu, Yahatahigashi-ku, Kitakyushu 805. 


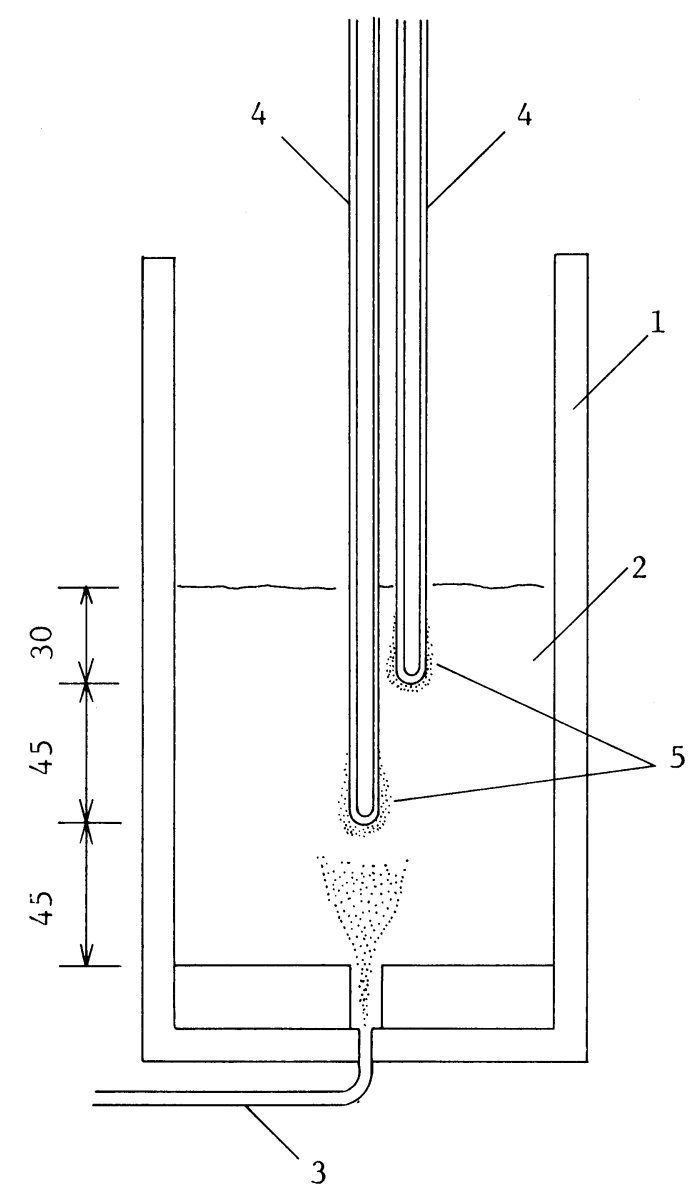

1: Magnesia crucible

2: Molten pig iron

3: Blowing nozzle

4: Alumina tube

5: Adhering slag

Fig. 1. Schematic illustration of sampling method of slag adhered. Two alumina tubes were immersed into the bath at the positions $45 \mathrm{~mm}$ and $90 \mathrm{~mm}$ above the blowing nozzle.

and electron scanning immages by EPMA were obtained.

Slags adhered were subjected to X-ray fluorescence analysis to determine the contents of total $\mathrm{Fe}, \mathrm{CaO}$, $\mathrm{SiO}_{2}, \mathrm{MnO}, \mathrm{P}_{2} \mathrm{O}_{5}, \mathrm{~S}, \mathrm{MgO}$ and $\mathrm{Al}_{2} \mathrm{O}_{3}$, and the contents of metallic $\mathrm{Fe}, \mathrm{FeO}$ and $\mathrm{Fe}_{2} \mathrm{O}_{3}$ were determined by ordinary chemical analysis.

2. Collecting Method of Reaction Products by means of Steel Samplers and Preparation of Samples

A $\mathrm{MgO}$ crucible was set in a high frequency induction furnace and low silicon pig iron (C: $4.33 \%$, Si : $0.02 \%, \mathrm{Mn}: 0.07 \%$, P: $0.108 \%$, S: $0.043 \%$ ) weighing $50 \mathrm{~kg}$ was melted. The experiment was done at $1350^{\circ} \mathrm{G}$. A triple layered lance (stainless steel pipe of $4 \mathrm{~mm}$ diameter in the inner part, magnesia pipe in the middle part and graphite pipe in the outer part) was used for injection. Lime powder weighing $200 \mathrm{~g}$ was injected for $11 \mathrm{~min}$ with a mixed gas $\left(\mathrm{O}_{2} 8 \mathrm{l} / \mathrm{min}+\mathrm{Ar} 4 \mathrm{l} / \mathrm{min}\right)$. During injection, the floating reaction product (slag) was collected together with hot metal by the steel sampler (see Fig. 2) immersed in the bath. Two kinds of sampler (a)
Table 1. Changes in composition of hot metal (\%).

\begin{tabular}{lccccc} 
& $\mathrm{C}$ & $\mathrm{Si}$ & $\mathrm{Mn}$ & $\mathrm{P}$ & $\mathrm{S}$ \\
\hline $\begin{array}{l}\text { Before flux } \\
\text { injection }\end{array}$ & 4.46 & 0.01 & 0.30 & 0.100 & 0.062 \\
$\begin{array}{l}\text { After flux } \\
\text { injection }\end{array}$ & 3.34 & 0.01 & 0.21 & 0.039 & 0.037 \\
\hline
\end{tabular}

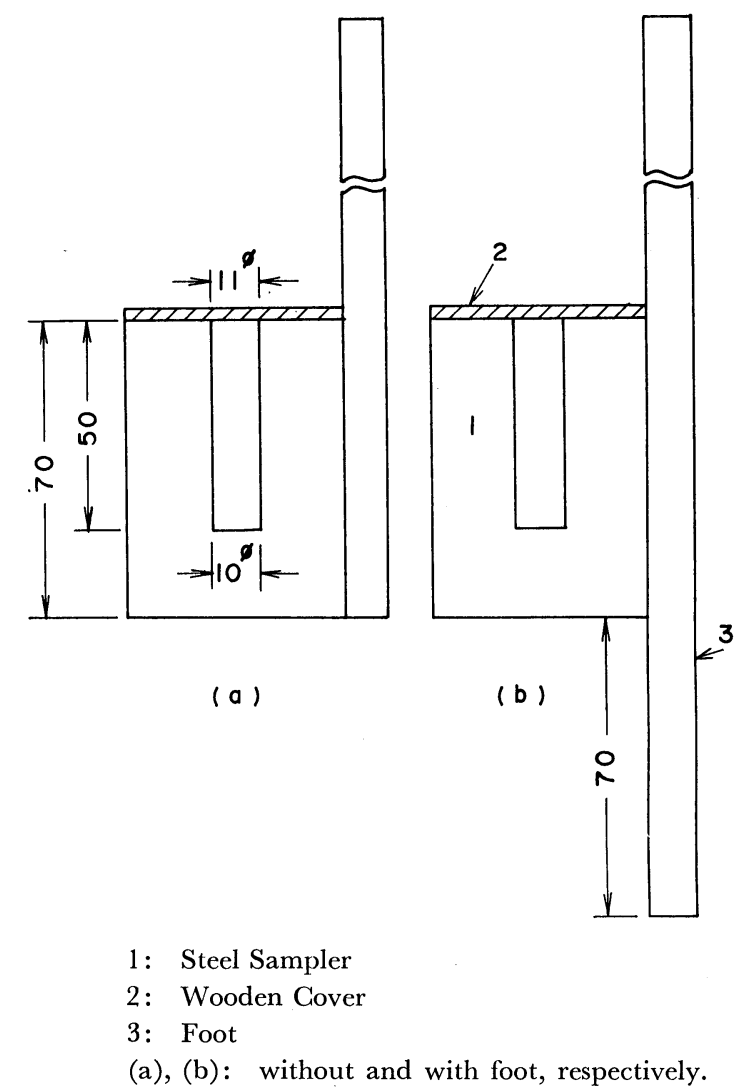

Fig. 2. Sampling apparatus used for collection of the reaction products with hot metal.

with and (b) without foot were used in order to collect the reaction product from two different positions. The sampler was quickly immersed into the bath up to the position where the bottom of sampler just reached the bottom of the crucible. Then, it was pulled up just after confirming that metal entered the sampler. Samples were subjected to the microscopic observation and the quantitative analysis by EPMA.

\section{Single-crystal Lime Lump Immersion Test}

A $\mathrm{MgO}$ crucible (inside diameter: $120 \mathrm{~mm}$, depth: $250 \mathrm{~mm}$ ) was set in a high frequency induction furnace and low-silicon pig iron (C: $3.14 \sim 3.79 \%, \mathrm{Si}$ : $0.01 \sim 0.03 \%$, Mn: $0.05 \sim 0.13 \%$, P: $0.075 \sim 0.200 \%$, $\mathrm{S}: 0.012 \sim 0.013 \%$ ) weighing $10 \mathrm{~kg}$ was melted. The experiment was done at $1350^{\circ} \mathrm{C}$. A single-crystal lime lump of $5 \mathrm{~mm} \times 5 \mathrm{~mm} \times 30 \mathrm{~mm}$ was set at the position $20 \mathrm{~mm}$ above the tip of the oxygen topblowing nozzle or three lumps were set as shown in Fig. 3 and those were kept in the immersed state for $60 \mathrm{~s}$. Oxygen was top-injected at a rate of $37.5 \mathrm{l} / \mathrm{min}$ with a graphite lance $30 \mathrm{~mm}$ outer diameter, $8 \mathrm{~mm}$ 
inner diameter and $500 \mathrm{~mm}$ long and bottom-blown at a rate of $8 \mathrm{l} / \mathrm{min}$ with copper tube $2 \mathrm{~mm}$ inner diameter. Further, iron oxide which is equivalent to $3.5 \mathrm{l} / \mathrm{min}$ of oxygen was added.

A single-crystal lime-lump after immersion was embedded in acrylic resin and cut off at the position $5 \mathrm{~mm}$ from its end, and the cut surface was ground with diamond paste. The ground surface was observed under an optical microscope to check the reaction layer. Gold vapour deposition was then done and the samples were subjected to line scanning by EPMA and the electron scanning images were obtained. Standard samples used for the quantitative analysis by EPMA are $\mathrm{Fe}, \mathrm{Mn}, \mathrm{Al}, \mathrm{Si}, \mathrm{Mg}, \mathrm{CaF}_{2}$, InP and $\mathrm{FeS}_{2}$. Only absorption correction was made, because the greatest error is induced by absorption.

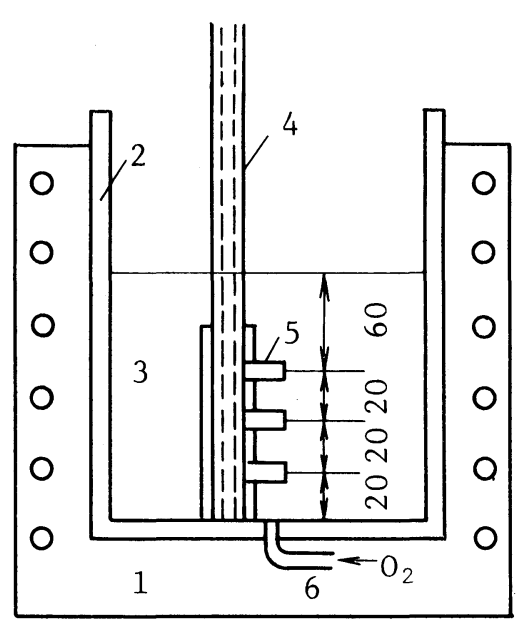

(a)

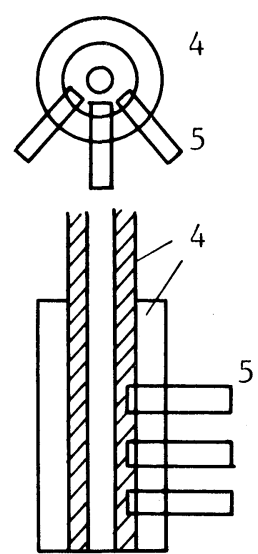

(b)
1: Induction furnace

2: Magnesia crucible

3: Molten pig iron

4: Holder (graphite)

5: Single crystal lime

6: $2 / 4 \phi$ Cu tube

(a): the apparatus

(b): the holder for single-crystal lime lumps

Fig. 3. Experimental apparatus for single-crystal lime lumps immersion test.

\section{Experimental Results}

\section{Lime Powder Injection Test}

\section{Investigation of Slag Adhered to $\mathrm{Al}_{2} \mathrm{O}_{3}$ Tube}

Table 1 shows the composition of hot metal before and after lime injection. Table 2 gives the average composition of slag adhered. It can be seen from Tables 1 and 2 that the percentage of dephosphorization is approximately $60 \%$ and that the $\mathrm{P}_{2} \mathrm{O}_{5}$ content of slag adhered is as high as $6.8 \%$. Thus, it is evident that dephosphorization proceeds to a great extent by lime injection. The slag adhered to $\mathrm{Al}_{2} \mathrm{O}_{3}$ tube is characterized by the fact that it contains a large amount of metallic iron and small amounts of $\mathrm{FeO}$ and $\mathrm{Fe}_{2} \mathrm{O}_{3}$.

Photograph 1 shows the optical micrographs of the outer part (hot metal side) of slag adhered, where (a) and (b) are the photographs of the samples taken at the positions $90 \mathrm{~mm}$ and $45 \mathrm{~mm}$ above the oxygen blowing nozzle, respectively. In Photo. 1 (a) four phases were observed, namely metallic iron, $\mathrm{CaS}$, $\mathrm{Ca}(\mathrm{Mn}) \mathrm{O}$ solid solution, and $\mathrm{CaO}-\mathrm{SiO}_{2}-\mathrm{P}_{2} \mathrm{O}_{5}$ solid solution as identified by EPMA.

On the contrary, $\mathrm{CaO}-\mathrm{SiO}_{2}-\mathrm{P}_{2} \mathrm{O}_{5}$ solid solution and $\mathrm{CaO}-\mathrm{Fe}(\mathrm{Mn})_{t} \mathrm{O}$ solid solution were observed in Photo. 1(b) but metallic iron was not observed in it.

Since the slag sampled at the position $90 \mathrm{~mm}$ above the oxygen blowing nozzle contains metallic iron particles but the slag sampled at the position $45 \mathrm{~mm}$ above the nozzle does not contain metallic iron, an investigation on the mechanism of the formation of iron particles was expected to provide a clue to the clarification of dephosphorization reaction. Therefore, a study was made on the distribution and composition of iron particles.

As shown in Photo. 1(a), it is the first feature that iron particles are very fine and are distributed only in the $\mathrm{Ca}(\mathrm{Mn}) \mathrm{O}$ solid solution. As given in Table 3, it is the second feature that the composition of iron particles $(\mathrm{C}=1.0 \sim 1.5 \%, \mathrm{Mn}=0.6 \sim 0.8 \%, \mathrm{P}=$ $0.67 \%$ [large particles] $0.01 \%$ [small particles]) is greatly different from that of hot metal $(\mathrm{C}=4.46 \%$, $\mathrm{Mn}=0.30 \%, \mathrm{P}=0.10 \%)$. Accordingly, it might be thought that $\left\{\mathrm{CaO}-\mathrm{Fe}(\mathrm{Mn})_{t} \mathrm{O}\right\}_{l}$ is reduced by carbon in hot metal to iron particles containing $\mathrm{C}, \mathrm{Mn}, \mathrm{P}$,
1. $\mathrm{Ca}(\mathrm{Mn}) \mathrm{O}$
2. Metallic iron
3. $\mathrm{CaO}-\mathrm{SiO}_{2}-\mathrm{P}_{2} \mathrm{O}_{5}$
4. $\mathrm{CaO}-\mathrm{Fe}(\mathrm{Mn})_{t} \mathrm{O}$ oxygen blowing nozzle.
(b) Sampled at the position $45 \mathrm{~mm}$ above the oxygen blowing nozzle.

Photo. 1.

Micrograph of adhered slag.

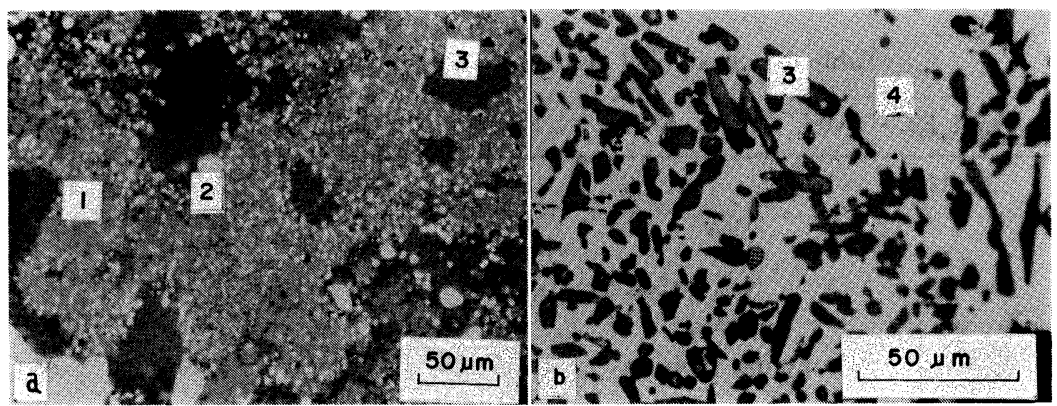

Table 2. Average composition of slag adhered. (\%)

\begin{tabular}{cccccccccccccccc}
\hline $\mathrm{T} . \mathrm{Fe}$ & $\mathrm{MFe}$ & $\mathrm{FeO}$ & $\mathrm{Fe}_{2} \mathrm{O}_{3}$ & $\mathrm{CaO}$ & $\mathrm{SiO}_{2}$ & $\mathrm{MnO}$ & $\mathrm{P}_{2} \mathrm{O}_{5}$ & $\mathrm{Al}_{2} \mathrm{O}_{3}$ & $\mathrm{MgO}$ & & & \\
\hline 21.2 & 18.8 & 0.82 & 2.51 & 45.3 & 1.31 & 5.27 & 6.84 & 0.91 & 5.82 & 2.96 & \\
\hline
\end{tabular}


etc. The reason why the phosphorus concentration of large iron particles is high is likely to be that these iron particles are formed by the reduction of highphosphorus containing slag at the position near the oxygen blowing nozzle where both of $\mathrm{CaO}-\mathrm{Fe}(\mathrm{Mn})_{t} \mathrm{O}$ and $\mathrm{CaO}-\mathrm{SiO}_{2}-\mathrm{P}_{2} \mathrm{O}_{5}$ are the liquid phase and that they grow thereafter. Precipitation of the solid $\mathrm{CaO}-$ $\mathrm{SiO}_{2}-\mathrm{P}_{2} \mathrm{O}_{5}$ phase containing phosphorus occurs when the $\mathrm{Fe}_{t} \mathrm{O}$ concentration decreases due to the reduction of molten slag, and it seems that small iron particles precipitate through the reduction by the remaining $\mathrm{CaO}-\mathrm{Fe}(\mathrm{Mn})_{t} \mathrm{O}$ melt of low phosphorus concentration. Therefore, these iron particles contain $\mathrm{Mn}$ and their phosphorus concentration is very low.

Thus, if many fine iron particles observed in slag are formed by the reduction of slag from the $\mathrm{Ca}(\mathrm{Mn}) \mathrm{O}$ phase, $\mathrm{CaO}-\mathrm{Fe}(\mathrm{Mn})_{t} \mathrm{O}$ molten slag of high $\mathrm{Fe}_{t} \mathrm{O}$ concentration is formed near the bottom blowing nozzle before reduction and the dephosphorization reaction is considered to proceed owing to the presence of this slag. On the other hand, it can be explained that at a position apart from the bottom blowing nozzle,

Table 3. Composition of iron particles in adhered slag analysed by EPMA (\%).

\begin{tabular}{c|ccccc}
\hline $\begin{array}{c}\text { Size of } \\
\text { iron } \\
\text { particle } \\
(\mu)\end{array}$ & $\mathrm{G}$ & $\mathrm{Si}$ & $\mathrm{Mn}$ & $\mathrm{P}$ & $\mathrm{S}$ \\
\hline 50 & 1.55 & 0.03 & 0.18 & 0.271 & 0.019 \\
\hline 35 & 1.97 & 0.02 & 0.87 & 0.667 & 0.021 \\
\hline 15 & 1.11 & 0.03 & 0.62 & 0.065 & 0.028 \\
& 0.64 & 0.02 & 0.64 & 0.044 & 0.023 \\
\hline 7 & 0.78 & 0.02 & 0.71 & 0.017 & 0.003 \\
\hline 5 & 1.38 & 0.02 & 0.68 & 0.016 & 0.013 \\
& 2.60 & 0.02 & 0.65 & 0.013 & 0.006 \\
\hline 4 & 1.78 & 0.01 & 0.69 & 0.010 & 0.035 \\
& 1.43 & 0.01 & 0.32 & 0.010 & 0.029 \\
\hline 3 & 1.43 & 0.05 & 0.62 & 0.004 & 0.031 \\
& 1.14 & 0.03 & 0.61 & 0.021 & 0.025 \\
& 1.09 & 0.02 & 0.60 & 0.010 & 0.027 \\
& 1.81 & 0.02 & 0.42 & 0.013 & 0.021
\end{tabular}

the formation of $\mathrm{CaO}-\mathrm{Fe}(\mathrm{Mn})_{t} \mathrm{O}$ slows down due to the decrease in available oxygen and that at the same time, the $\mathrm{Fe}(\mathrm{Mn})_{t} \mathrm{O}$ concentration decreases because of the reduction of formed $\mathrm{CaO}-\mathrm{Fe}(\mathrm{Mn})_{t} \mathrm{O}$ so that the dephosphorization reaction becomes difficult to occur.

\section{Investigation of Slag Collected by Steel Sampler}

Table 4 gives the analytical results of slag sampled from the top of the bath after the termination of injection. This slag is characterized by the existence of a large amount of metallic iron and by high concentrations of $\mathrm{Al}_{2} \mathrm{O}_{3}$ and $\mathrm{MgO}$. High concentration of $\mathrm{Al}_{2} \mathrm{O}_{3}$ is originated from the use of alumina protection tube for thermocouple, and that of $\mathrm{MgO}$ is derived from the use of magnesia crucible. Then, the concentration of $\mathrm{Al}_{2} \mathrm{O}_{3}$ is important as a tracer to identify the sampling position.

Table 5 gives the results of a quantitative analysis of these slags by EPMA. Photograph 2 shows the electron scanning images of the slag taken at the position $10 \mathrm{~mm}$ above the blowing nozzle. Since $\mathrm{Al}_{2} \mathrm{O}_{3}$ concentration of No. 5 slag in Table 5 is high, it seems to be a top slag which is recirculated into bath. Other slags are judged to have been sampled at a fixed position.

The reason why the total concentration is less than $100 \%$ seems to be that the samples of slag are porous or rough. Figure 4 shows the relationship between the sampling positions of slag and the concentration of $\mathrm{FeO}$.

The $\mathrm{FeO}$ concentrations in Fig. 4 are shown as a percentage after the total percentage is corrected so as to be $100 \%$.

It is evident in Photo. 2 that the dephosphorization reaction has already taken place near the blowing nozzle. It is also shown that the $\mathrm{FeO}$ concentration of the slag sampled near the blowing nozzle is high, whereas that of the slag sampled at a position apart from the nozzle is low. As previously mentioned, these facts support the postulation that $\{\mathrm{CaO}$ $\left.\mathrm{Fe}(\mathrm{Mn})_{t} \mathrm{O}\right\}_{l}$ is formed near the blowing nozzle, and the $\mathrm{Fe}(\mathrm{Mn})_{t} \mathrm{O}$ concentration decreases through the reduction by carbon on its floating.

\section{Single-crystal Lime Lump Immersion Test}

Photograph 3 shows a micrograph of the section of

Table 4. Analytical results of slag sampled from top of the bath after the termination of injection. (\%)

\begin{tabular}{cccccccccccc}
\hline Total $\mathrm{Fe}$ & $\mathrm{Met} . \mathrm{Fe}$ & $\mathrm{FeO}$ & $\mathrm{Fe}_{2} \mathrm{O}_{3}$ & $\mathrm{CaO}$ & $\mathrm{SiO}_{2}$ & $\mathrm{Al}_{2} \mathrm{O}_{3}$ & $\mathrm{MgO}$ & $\mathrm{MnO}$ & $\mathrm{P}_{2} \mathrm{O}_{5}$ & $\mathrm{~S}$ \\
\hline 24.83 & 18.23 & 1.66 & 7.59 & 37.19 & 1.34 & 13.82 & 13.05 & 0.68 & 5.06 & 0.75 \\
\hline
\end{tabular}

Table 5. Analytical results of slags floating up in hot metal by EPMA. (\%)

\begin{tabular}{c|c|rrrrrrrr}
\hline $\begin{array}{c}\text { Sample } \\
\text { No. }\end{array}$ & Sampling position & $\mathrm{FeO}$ & $\mathrm{CaO}$ & $\mathrm{SiO}_{2}$ & $\mathrm{Al}_{2} \mathrm{O}_{3}$ & $\mathrm{MgO}$ & $\mathrm{P}_{2} \mathrm{O}_{5}$ & $\mathrm{~S}$ & $\mathrm{Total}$ \\
\hline 1 & $10 \mathrm{~mm}$ above nozzle & 30.00 & 5.74 & 5.01 & 0.47 & 0.73 & 0.98 & 0.15 & 43.08 \\
2 & $\#$ & 16.28 & 22.74 & 2.76 & 0.69 & 1.36 & 12.05 & 1.21 & 57.09 \\
3 & $\#$ & 16.66 & 31.11 & 25.01 & 0.57 & 2.02 & 8.13 & 1.89 & 85.39 \\
4 & $80 \mathrm{~mm}$ above nozzle & 6.87 & 43.85 & 2.42 & 0.77 & 0.27 & 22.22 & 0.26 & 76.66 \\
5 & $\#$ & 8.44 & 3.58 & 17.25 & 6.63 & 2.77 & 9.78 & 1.50 & 49.95 \\
\hline
\end{tabular}


a single-crystal lime lump immersed for $60 \mathrm{~s}$ during oxygen blowing. This photograph clearly shows a layer indicating the beginning of $\mathrm{CaO}$ slagging (I) and a slag layer $(\mathrm{II} \sim \mathrm{IV})$. In this case, the thickness of the layer indicating the beginning of slagging and that of the slag layer were $30 \mu$ and $150 \mu$, respectively.

Photograph 4 shows the electron scanning images of the layer indicating the beginning of slagging and the succeeding reaction layer taken by EPMA. The layer indicating the beginning of slagging shows that Fe and Mn are concentrated (see Fig. 5). However, the penetration of $\mathrm{P}$ into the layer was found to be very little. High concentrations of $\mathrm{Ca}, \mathrm{Fe}, \mathrm{Si}$ and $\mathrm{P}$ were observed in the slag layer.

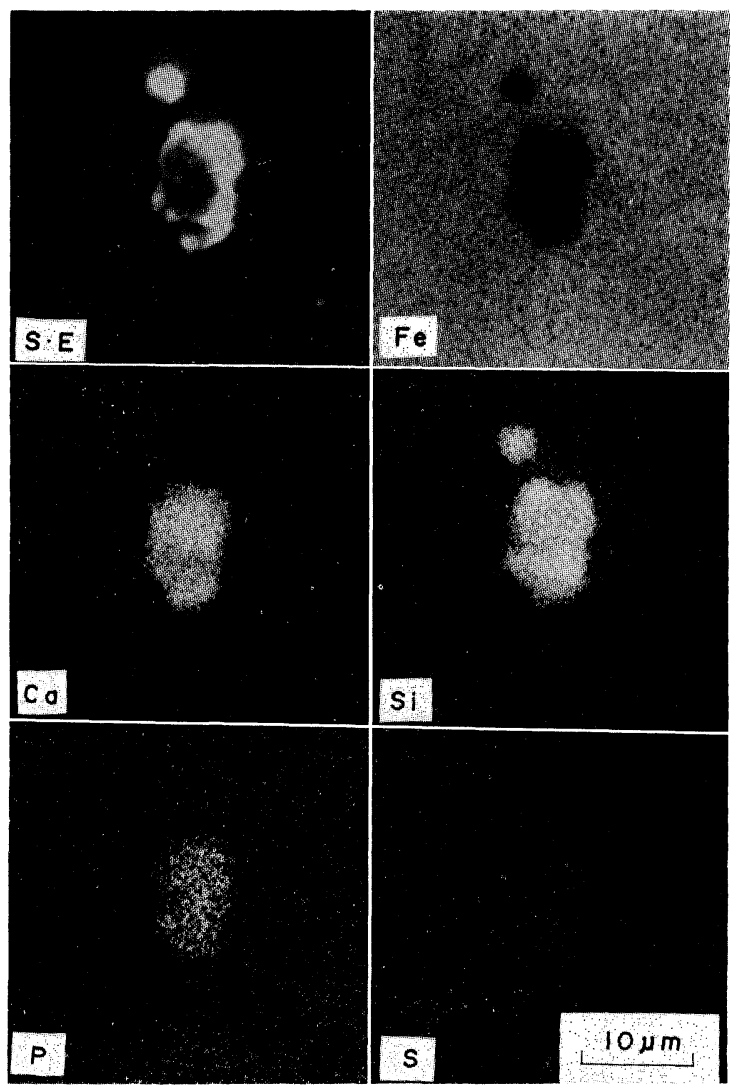

Photo. 2. Electron scanning images of the reaction product sampled at the position $10 \mathrm{~mm}$ above the injection nozzle.
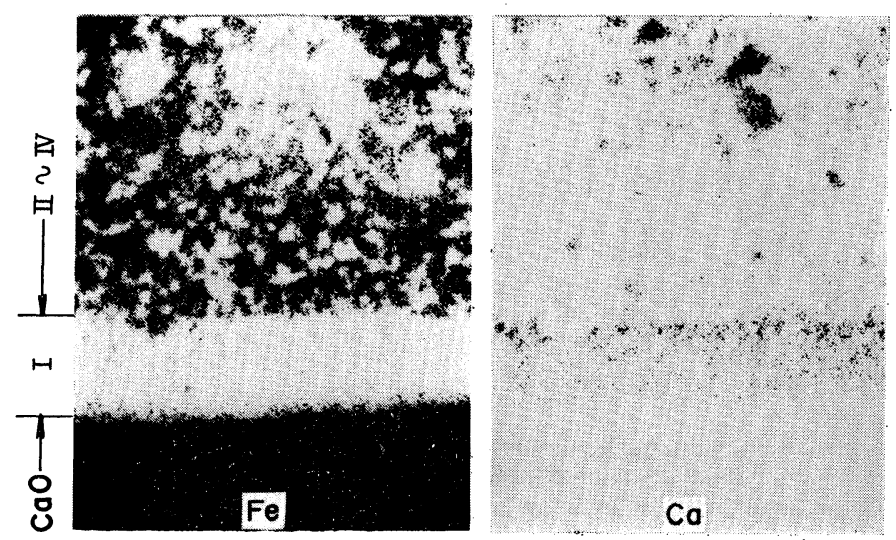

I: Layer slag formation initiating

II IV: Slag layer

Photo. 4. Electron scanning images of lime single-crystal immersed in hot metal for $60 \mathrm{~s}$.
Figure 5 shows the results of line scanning of the reaction layer by EPMA. It is possible to divide the reaction layer into four parts according to the features of the distribution of each element.

Layer I which is in contact with $\mathrm{CaO}$ shows high concentrations of $\mathrm{Fe}$ and $\mathrm{Mn}$ and low concentrations of $\mathrm{P}$ and Si. This is the layer indicating the beginning

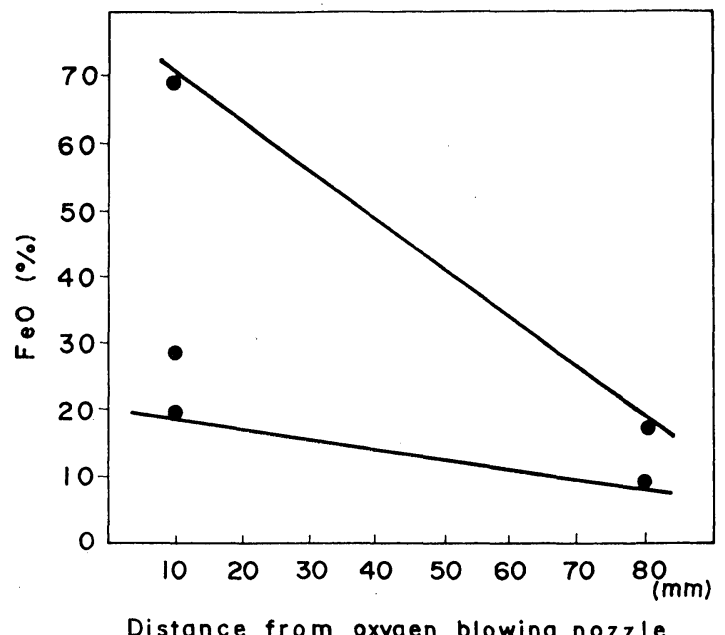

Fig. 4. Relationship between the sampling position of slag and the concentration of $\mathrm{FeO}$.

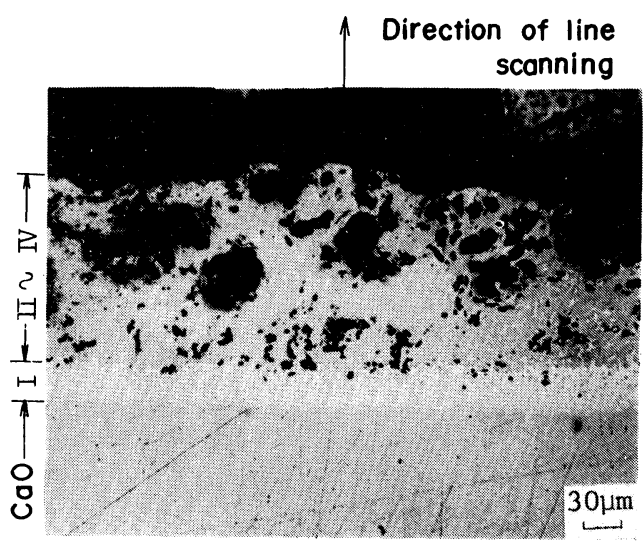

I: Layer slag formation initiating II IV: Slag layer

Photo. 3. Microstructure of the cross-section of lime singlecrystal immersed in hot metal for $60 \mathrm{~s}$.
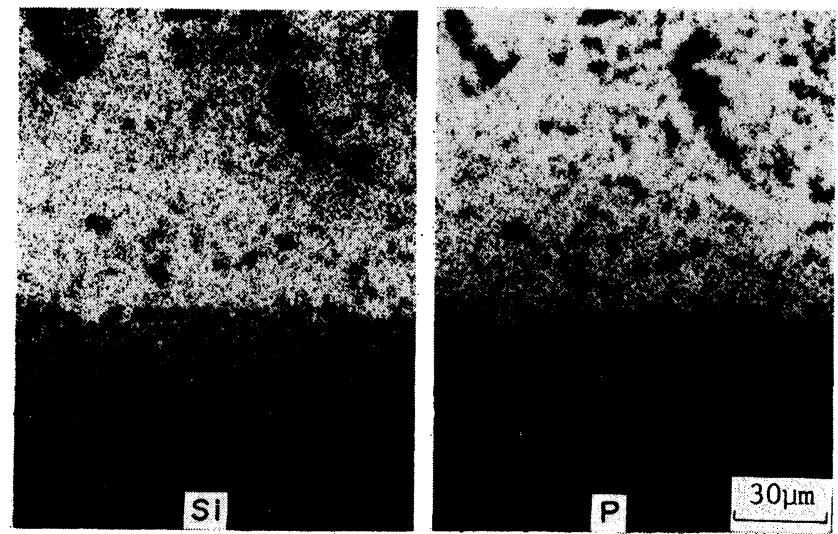

$P$ 
of slagging. Layer II shows high concentrations of $\mathrm{Fe}$ and $\mathrm{Mn}$ and the slagging of $\mathrm{CaO}$ is considered to be under way in this layer. The penetration of $\mathrm{P}$ has taken place in this layer. Layer III has high
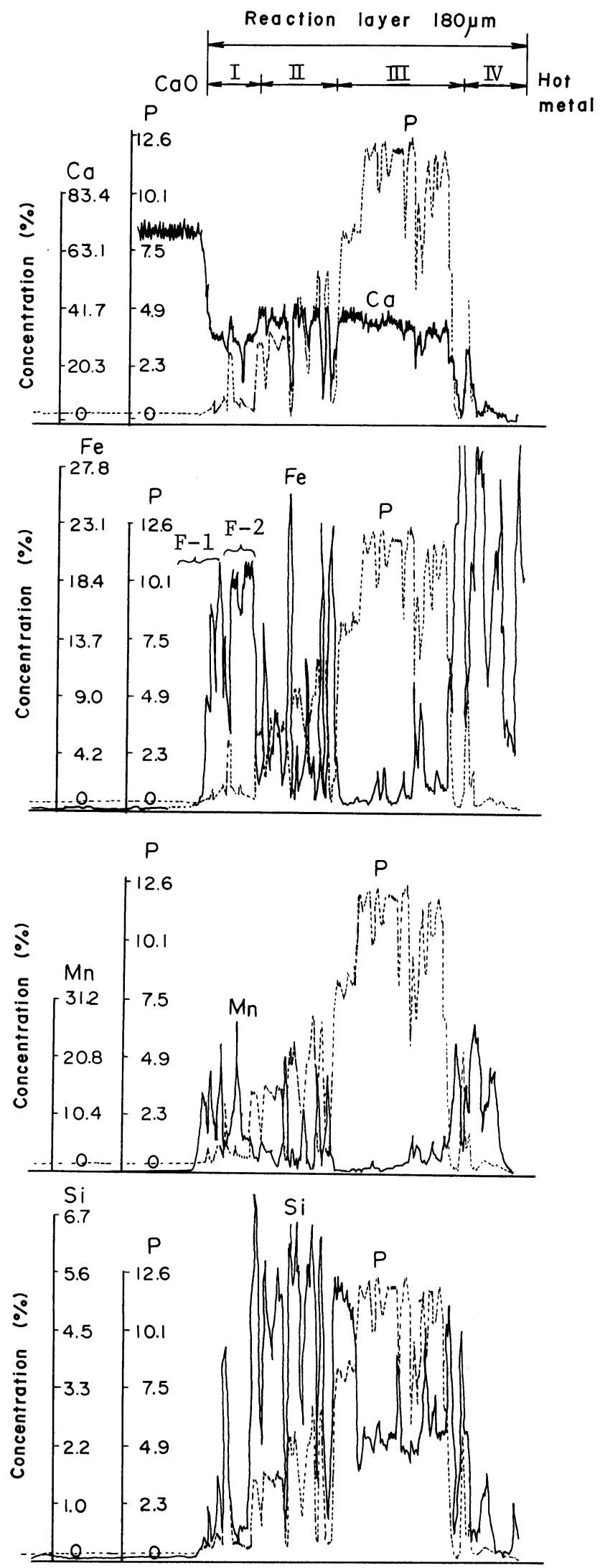

Fig. 5. Concentration profiles of the reaction layer obtained by EPMA. concentrations of $\mathrm{P}, \mathrm{Si}$ and $\mathrm{Ca}$ and very low concentration of $\mathrm{Fe}$ and $\mathrm{Mn}$. Therefore, the composition of this layer is considered to be $\left(\mathrm{CaO}-\mathrm{SiO}_{2}-\mathrm{P}_{2} \mathrm{O}_{5}\right)_{\mathrm{s.s}}$. Layer IV has very high concentrations of $\mathrm{Fe}$ and $\mathrm{Mn}$, and $\mathrm{Ca}$ is also observed. Therefore, the composition of this layer is considered to be $\left\{\mathrm{CaO}-\mathrm{Fe}(\mathrm{Mn})_{t} \mathrm{O}\right\}_{l}$.

To identify the phosphorus containing phases of $\left.\mathrm{CaO}-\mathrm{SiO}_{2}-\mathrm{P}_{2} \mathrm{O}_{5}\right)$ mineralogically, concentrations of $\mathrm{Ca}, \mathrm{Si}, \mathrm{Fe}, \mathrm{Mn}$ and $\mathrm{P}$ at each peak of $\mathrm{P}$ were read from Fig. 5 and the compositions of $\mathrm{CaO}, \mathrm{SiO}_{2}, \mathrm{FeO}$, $\mathrm{MnO}$ and $\mathrm{P}_{2} \mathrm{O}_{5}$ were calculated. The phosphorus containing mineral phases were identified by molar composition ratios of $\mathrm{CaO}, \mathrm{SiO}_{2}$ and $\mathrm{P}_{2} \mathrm{O}_{5}$.

The phosphorus containing mineral phase of Layer III was identified as either nagelschmidtite $(7 \mathrm{CaO}$. $\left.2 \mathrm{SiO}_{2} \cdot \mathrm{P}_{2} \mathrm{O}_{5}\right)$ or silicocarnotite $\left(5 \mathrm{CaO} \cdot \mathrm{SiO}_{2} \cdot \mathrm{P}_{2} \mathrm{O}_{5}\right)$.

To identify the phase in reaction Layers I to IV during dephosphorization at $1350^{\circ} \mathrm{C}$, compositions of the phosphorus-containing phase (P-phase) and the iron oxide-containing phase (F-phase) in each layer of the reaction layer were estimated from Fig. 5 and are shown in Table 6. Further, each phase was regarded as the pseudo-ternary system of $\mathrm{CaO}^{\prime}-$ $\left(\mathrm{SiO}_{2}+\mathrm{P}_{2} \mathrm{O}_{5}\right)^{\prime}-(\mathrm{FeO}+\mathrm{MnO})^{\prime}$ and the liquidus temperature $\left(T_{L L}\right)$ and solidus temperature $\left(T_{S L}\right)$ of each phase were calculated by assuming that the phase diagram of the $\mathrm{CaO}-\mathrm{SiO}_{2}-\mathrm{FeO}$ system $^{13)}$ can be applied to the pseudo-ternary system.

As a result, it was found that in Layer I, i.e., near the starting location of slagging, only some F-phases were detected. And the liquidus and solidus temperatures are calculated from their compositions. In Layer $\mathrm{I}$, since the experimental temperature $\left(1350{ }^{\circ} \mathrm{C}\right)$ is lower than $T_{S L}$ or between $T_{L L}$ and $T_{S L}$, those F-phases are solid or solid and liquid mixtures. The P-phase in Layer II, in the same manner, is a solid phase, while the F-phase in this layer is close to a liquid phase. In Layer III, the P-phase is a solid phase and the F-phase is a solid and liquid mixture. In this layer, however, the proportion of the P-phase is high. Therefore, it is presumed that as a whole, the liquid phase exist at the grain

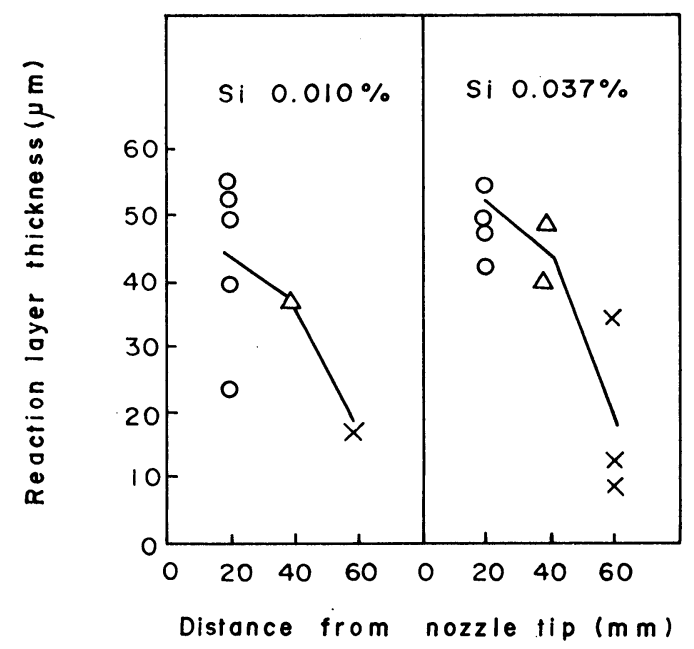

Fig. 6. Changes in the reaction layer thickness formed on single-crystal lime (after immersion for $60 \mathrm{~s}$ at $1350{ }^{\circ} \mathrm{C}$. 
boundaries of solid particles. In Layer IV, the $\mathrm{P}$-phase is in a solid and liquid coexisting state, and the F-phase is high in proportion, suggesting the predominance of liquid phase as a whole.

Figure 6 shows the reaction layer thickness of single-crystal lime samples immersed for $60 \mathrm{~s}$ at the positions 20, 40 and $60 \mathrm{~mm}$ apart from the furnace bottom during the bottom blowing of oxygen into hot metal. The reaction layer thickness decreases with increasing distance from the furnace bottom, i.e., oxygen blowing nozzle.

Further, the effect of iron oxide addition was studied under the condition that the total amount of oxygen consumption was constant. Figures 7 and 8 show the results obtained when a part of oxygen was replaced by iron oxide. The reaction layer thickness and the concentration of phosphorus in the layer decrease more slightly in the case of iron oxide addition with increasing distance from the furnace bottom than the case without iron oxide injection. Therefore, it is so judged that the range of dephosphorization reaction is enlarged by the addition of iron oxide.

\section{Discussion}

\section{Slagging Process of Lime in Hot Metal}

Photographs 3 and 4 clearly show a layer indicating the beginning of $\mathrm{CaO}$ slagging. As is apparent from Fig. 5, the concentrations of $\mathrm{Fe}$ and $\mathrm{Mn}$ are very

Table 6. Identification of the phase in reaction Layers I IV during dephosphorization at $1350^{\circ} \mathrm{C}$.

\begin{tabular}{|c|c|c|c|c|c|c|c|c|c|}
\hline \multirow{2}{*}{$\begin{array}{l}\text { Position } \\
\text { in } \\
\text { reaction } \\
\text { layer }\end{array}$} & \multirow{2}{*}{$\begin{array}{l}\text { Mineral } \\
\text { phase }\end{array}$} & \multicolumn{5}{|c|}{ Composition (\%) } & \multicolumn{2}{|c|}{$\begin{array}{l}\text { Temperature calculated } \\
\text { from phase diagram }\end{array}$} & \multirow{2}{*}{$\begin{array}{l}\text { State of phase } \\
\text { (at } 1350^{\circ} \mathrm{C} \text { ) }\end{array}$} \\
\hline & & $\mathrm{CaO}$ & $\mathrm{SiO}_{2}$ & $\mathrm{FeO}$ & $\mathrm{MnO}$ & $\mathrm{P}_{2} \mathrm{O}_{5}$ & $T_{L L}\left({ }^{\circ} \mathrm{C}\right)$ & $\mathcal{T}_{S L}\left({ }^{\circ} \mathrm{C}\right)$ & \\
\hline \multirow{2}{*}{ I } & F-1 & 53.5 & 4.2 & 31.1 & 8.3 & 2.9 & $\fallingdotseq 1750$ & $\fallingdotseq 1570$ & solid \\
\hline & $\mathrm{F}-2$ & 32.1 & 1.0 & 33.3 & 30.4 & 3.2 & $\fallingdotseq 1400$ & $\fallingdotseq 1210$ & solid+liquid \\
\hline \multirow{2}{*}{ II } & $\mathrm{P}$ & 65.6 & 17.0 & 1.1 & 1.5 & 14.8 & $\fallingdotseq 2080$ & $\fallingdotseq 1960$ & solid \\
\hline & $\mathrm{F}$ & 20.6 & 2.0 & 41.8 & 34.5 & 1.1 & $\fallingdotseq 1380$ & $\fallingdotseq 1220$ & solid+liquid \\
\hline \multirow{2}{*}{ III } & $\mathbf{P}$ & 59.1 & 6.2 & 0.5 & 1.5 & 32.7 & $\fallingdotseq 1810$ & $\fallingdotseq 1450$ & solid \\
\hline & $\mathrm{F}$ & 50.3 & 6.1 & 15.4 & 8.9 & 21.0 & $\fallingdotseq 1830$ & $\fallingdotseq 1280$ & solid+liquid \\
\hline \multirow{2}{*}{ IV } & $\mathrm{P}$ & 51.2 & 13.2 & 11.5 & 6.8 & 17.3 & $\fallingdotseq 1820$ & $\fallingdotseq 1250$ & solid+liquid \\
\hline & $\mathrm{F}$ & 6.0 & 0.9 & 48.6 & 44.5 & 0 & $\doteqdot 1320$ & $\fallingdotseq 1200$ & liquid \\
\hline
\end{tabular}

* P : Phosphorus oxide containing phase, F : Iron oxide containing phase

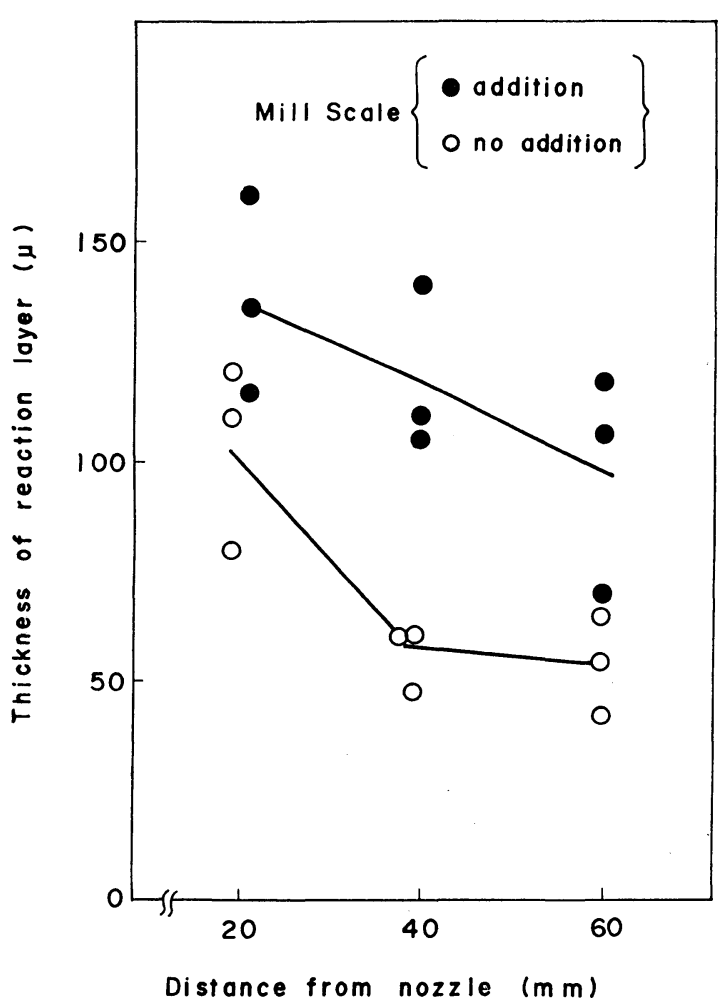

Fig. 7. Relationship between the distance from oxygen blowing nozzle and the thickness of reaction layer of lime during iron oxide injection.

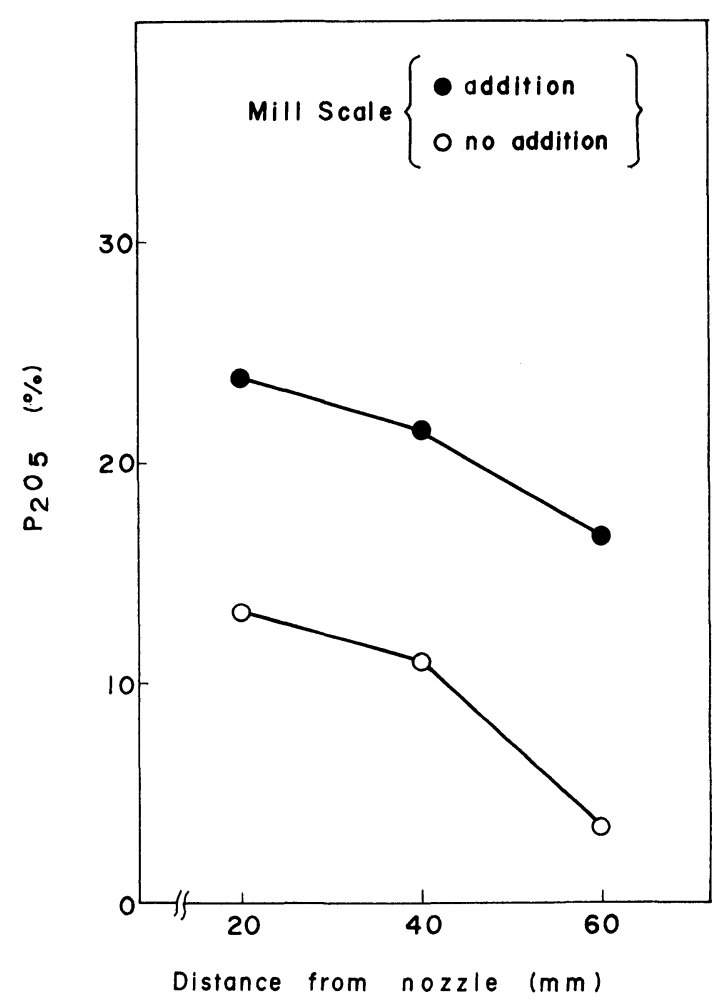

Fig. 8. Relationship between the distance from oxygen blowing nozzle and the average concentration of $\mathrm{P}_{2} \mathrm{O}_{5}$ in the reaction layer during iron oxide injection. 
high in this layer and it can be said that slagging takes place owing to the formation of $\mathrm{CaO}-\mathrm{Fe}(\mathrm{Mn})_{t} \mathrm{O}$ by the reaction of $\mathrm{Fe}(\mathrm{Mn})_{t} \mathrm{O}$ and $\mathrm{CaO}$. If silicon is contained in hot metal, the slag is naturally $\mathrm{CaO}-$ $\mathrm{Fe}(\mathrm{Mn})_{t} \mathrm{O}-\mathrm{SiO}_{2}$. An investigation was made in the initial stage of slagging, and the results obtained revealed that the concentrations of $\mathrm{Fe}, \mathrm{Mn}$ and $\mathrm{Si}$ are all high. This fact proved that the reaction of $\mathrm{CaO}$ and $\mathrm{P}$ begins after the diffusion of $\mathrm{Fe}, \mathrm{Mn}$ and $\mathrm{Si}$ into $\mathrm{CaO}$. On the other hand, the peaks of $\mathrm{P}$ and Fe are always inverse outside the F-2 phase of Layer $\mathrm{I}$, i.e., the part which is high in phosphorus is poor in iron, and on the contrary, the part which is high in iron is poor in phosphorus. From Table 6, this F-2 phase is considered to be a mixture of solid and liquid phases at the experimental temperature $\left(1350^{\circ} \mathrm{C}\right.$ ), and it might be thought that after the reaction with phosphorus, a different phase has precipitated from liquid slag in the cooling process.

In Layer II, the concentrations of $\mathrm{Fe}, \mathrm{Mn}, \mathrm{Ca}$, $\mathrm{Si}$ and $\mathrm{P}$ are not uniform and the peak of each component indicates $\left(\mathrm{CaO}-\mathrm{SiO}_{2}-\mathrm{P}_{2} \mathrm{O}_{5}\right)_{s}$ [P-phase] and $\left\{\mathrm{CaO}-\mathrm{Fe}(\mathrm{Mn})_{t} \mathrm{O}-\mathrm{SiO}_{2}-\mathrm{P}_{2} \mathrm{O}_{5}\right\}_{l}\left[\mathrm{~F}\right.$-phase], where, $T_{L L}$ and $T_{S L}$ of F-phase are about $1380^{\circ} \mathrm{C}$ and $1200^{\circ} \mathrm{C}$, respectively. Therefore, slagging is considered to have proceeded considerable in this layer.

From these results, it is thought that $\mathrm{CaO}$ injected into hot metal slaggs to form $\left\{\mathrm{CaO}-\mathrm{Fe}(\mathrm{Mn})_{t} \mathrm{O}\right\}_{l}$ at first which reacts with phosphorus later.

\section{Mechanism of Dephosphorization during Lime Injection by Oxygen}

The dephosphorization mechanism of hot metal by $\mathrm{CaO}$ was reasoned as follows and showed in Fig. 9 on the basis of the results of the single-crystal lime immersion and lime injection tests. When $\mathrm{CaO}$ is injected into hot metal with oxygen, oxidation of $\mathrm{Si}$, $\mathrm{Mn}, \mathrm{Fe}$ and $\mathrm{C}$ takes place near the fire point of the blowing nozzle.

$$
\underline{\mathrm{Si}}+\mathrm{O}_{2} \rightarrow \mathrm{SiO}_{2}
$$

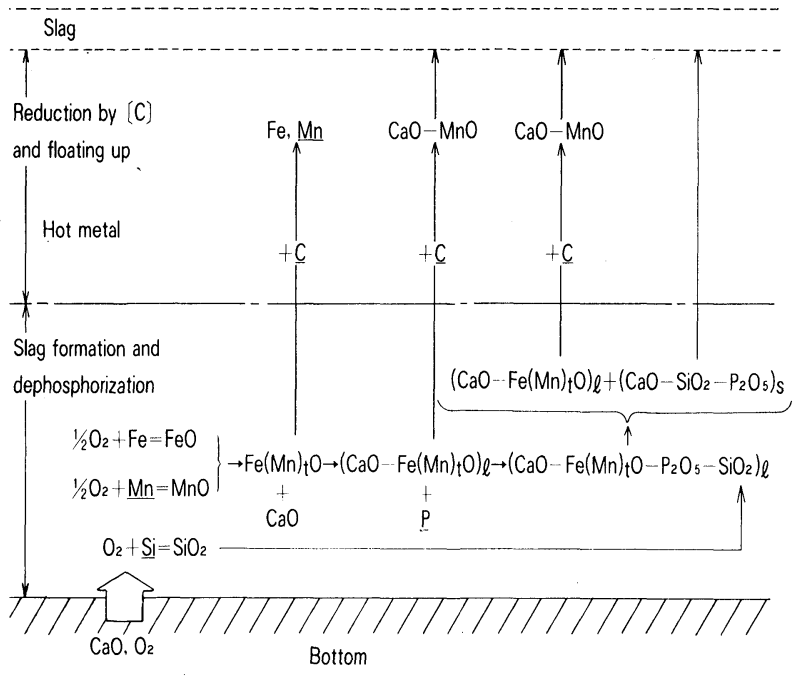

Fig. 9. Schematic illustration of the dephosphorization mechanism of hot metal by lime injection.

$$
\left.\begin{array}{c}
\underline{\mathrm{Mn}}+\mathrm{O}_{2} \rightarrow \mathrm{Mn}_{t} \mathrm{O} \\
\mathrm{Fe}+\mathrm{O}_{2} \rightarrow \mathrm{Fe}_{t} \mathrm{O} \\
\underline{\mathrm{C}}+1 / 2 \mathrm{O}_{2} \rightarrow \mathrm{CO} \uparrow
\end{array}\right\}
$$

Equation (3) is not referred to here because CO gas does not directly participate in the dephosphorization reaction. $\left\{\mathrm{CaO}-\mathrm{Fe}(\mathrm{Mn})_{t} \mathrm{O}\right\}_{l}$ is then formed by the reactions of $\mathrm{CaO}$ with $\mathrm{Mn}_{t} \mathrm{O}_{t}$ and $\mathrm{Fe}_{t} \mathrm{O}$.

$$
\left.\begin{array}{l}
\mathrm{CaO}+\mathrm{Fe}_{t} \mathrm{O} \\
\mathrm{CaO}+\mathrm{Mn}_{t} \mathrm{O}
\end{array}\right\} \rightarrow\left\{\mathrm{CaO}-\mathrm{Fe}(\mathrm{Mn})_{t} \mathrm{O}\right\}_{t}
$$

The dephosphorization reaction begins at the interface between this multicomponent liquid and hot metal.

$$
\begin{aligned}
& \left\{\mathrm{CaO}-\mathrm{Fe}(\mathrm{Mn})_{t} \mathrm{O}\right\}_{l}+\underline{\mathrm{P}} \\
& \quad \rightarrow\left\{\mathrm{CaO}-\mathrm{Fe}(\mathrm{Mn})_{t} \mathrm{O}-\mathrm{P}_{2} \mathrm{O}_{5}\right\}_{l}+\mathrm{Fe}_{s}
\end{aligned}
$$

When Eq. (5) proceeds and the $\mathrm{P}_{2} \mathrm{O}_{5}$ concentration becomes high, solid phases such as silicocarnotite and nagelschmidtite precipitate since $\mathrm{SiO}_{2}$ is included in the liquid slag.

$$
\begin{aligned}
& \left\{\mathrm{CaO}-\mathrm{Fe}(\mathrm{Mn})_{t} \mathrm{O}-\mathrm{SiO}_{2}-\mathrm{P}_{2} \mathrm{O}_{5}\right\}_{l} \\
& \quad \rightarrow\left(\mathrm{CaO}-\mathrm{SiO}_{2}-\mathrm{P}_{2} \mathrm{O}_{5}\right)_{s}+\left\{\mathrm{CaO}-\mathrm{Fe}(\mathrm{Mn})_{t} \mathrm{O}\right\}_{l}
\end{aligned}
$$

Liberated $\mathrm{Fe}_{s}$ in $\mathrm{Eq}$. (5) reacts with carbon in hot metal. As a result, its melting point drops and it melts.

$$
\mathrm{Fe}_{s}+\underline{\mathrm{C}} \rightarrow[\mathrm{Fe}-\mathrm{C}]_{l}
$$

With an increase in distance from the oxygen blowing nozzle, the concentrations of $\mathrm{Fe}_{t} \mathrm{O}$ and $\mathrm{Mn}, \mathrm{O}$ at the $\mathrm{CaO}$ interface decrease because the blown oxygen is consumed by decarburization, etc., and Eq. (4) becomes hard to occur. Further, it is presumed that the reduction of the reaction product by carbon also takes place.

$$
\begin{aligned}
& \left\{\mathrm{CaO}-\mathrm{Fe}(\mathrm{Mn})_{t} \mathrm{O}\right\}_{l}+\underline{\mathrm{G}} \\
& \quad \rightarrow \mathrm{Ca}(\mathrm{Mn}) \mathrm{O}_{s}+[\mathrm{Fe}-\mathrm{Mn}-\mathrm{C}]_{s} \\
& {[\mathrm{Fe}-\mathrm{Mn}-\mathrm{C}]_{s}+\underline{\mathrm{G}} \rightarrow[\mathrm{Fe}-\mathrm{Mn}-\mathrm{C}]_{l}}
\end{aligned}
$$

From the results of the single-crystal lime immersion and lime injection tests, it is conceived that dephosphorization during $\mathrm{CaO}$ injection with oxygen occurs mainly near the oxygen blowing nozzle.

This is because at a position apart from the nozzle, the reaction of Eq. (4) becomes hard to occur and the amount of $\left\{\mathrm{CaO}-\mathrm{Fe}_{t} \mathrm{O}-\mathrm{Mn}_{t} \mathrm{O}\right\}_{l}$ decreases as a result of Eq. (8).

\section{Conclusion}

An investigation was made on the mechanism of dephosphorization during $\mathrm{CaO}$ injection with oxygen by single-crystal lime immersion and lime injection tests, and the followings were made clear:

(1) Slagging of $\mathrm{CaO}$ in hot metal takes place in the process of $\left\{\mathrm{CaO}-\mathrm{Fe}(\mathrm{Mn})_{t} \mathrm{O}\right\}_{\iota}$ formation through the reaction of $\mathrm{CaO}$ with $\mathrm{Fe}_{t} \mathrm{O}$ and $\mathrm{Mn}_{t} \mathrm{O}$ near the oxygen blowing nozzle.

(2) The dephosphorization proceeds when $\{\mathrm{CaO}-$ 
$\left.\mathrm{Fe}(\mathrm{Mn})_{t} \mathrm{O}\right\}_{l}$ of high $\mathrm{Fe}_{t} \mathrm{O}$ concentration is present. When the $\mathrm{P}_{2} \mathrm{O}_{5}$ concentration in the reaction layer increases, $\mathrm{SiO}_{2}$ present in slag also participates in the reaction and the concentration of $\mathrm{Fe}(\mathrm{Mn})_{t} \mathrm{O}$ decreases, solid phases of $\left(\mathrm{CaO}-\mathrm{SiO}_{2}-\mathrm{P}_{2} \mathrm{O}_{5}\right)_{s}$, such as nagelschmidtite and silicocarnotite, precipitate.

(3) These reactions proceed in a short period of time at a position near the oxygen blowing nozzle. The amount of oxygen supplied becomes insufficient at a position apart from the oxygen blowing nozzle. Therefore, the formation of $\left\{\mathrm{CaO}-\mathrm{Fe}(\mathrm{Mn})_{t} \mathrm{O}\right\}_{l}$ slows down and reduction of $\left\{\mathrm{CaO}-\mathrm{Fe}(\mathrm{Mn})_{t} \mathrm{O}\right\}_{l}$ by $\underline{\mathrm{C}}$ takes place. Accordingly, the dephosphorization reaction becomes hard to occur. By the addition of iron oxide together with oxygen, the region where $\{\mathrm{CaO}-$ $\left.\mathrm{Fe}(\mathrm{Mn})_{t} \mathrm{O}\right\}_{l}$ reacts can be enlarged. In order to promote the dephosphorization reaction, it is necessary to form $\left\{\mathrm{CaO}-\mathrm{Fe}(\mathrm{Mn})_{t} \mathrm{O}\right\}_{l}$ of high $\mathrm{Fe}_{t} \mathrm{O}$ concentration at an early stage.

In this sense, it is important to blow oxygen and is effective to inject iron oxide together with oxygen in order to enlarge the region where $\{\mathrm{CaO}-\mathrm{Fe}$ $\left.(\mathrm{Mn})_{t} \mathrm{O}\right\}_{l}$ reacts.

\section{Acknowledgements}

The authors wish to express their sincere thanks to Professor Kazumi Ogino, Mr. Jun Nishiwaki and Mr. Kiyoshi Nogi of Osaka University and Professor Kazu- mi Mori of Nagoya University for helpful discussions in preparing this paper.

\section{REFERENCES}

1) G. König, H. Rellermeyer: Stahl u. Eisen, 87 (1967), 1071.

2) F. Bardenheuer, H. vom Ende and P. G. Oberhäuser: Stahl u. Eisen, 88 (1968), 1285.

3) L. Hachtel, W. Fix and G. Trömel: Arch. Eisenhüttenw., 43 (1972), 361.

4) K. H. Obst and J. Stradtmann: Arch. Eisehnüttenw., 40 (1969), 8, 615.

5) E. Schürmann, N. Nürnberg, W. Ullich and E. Overkott : Arch. Eisenhüttenw., 39 (1968), 815.

6) R. Scheel and F. Oeters: Arch. Einsenhüttenw., 42 (1971), 769.

7) F. Bardenheuer, G. Kauder and L. von Wedel: Arch. Eisenhüttenw., 44 (1973), 111.

8) F. Oeters and R. Scheel: Arch. Einsenhüttenw., 45 (1974), 575.

9) M. Matsushima, S. Yadoomaru, K. Mori and Y. Kawai : Tetsu-to-Hagané, 62 (1976), 182.

10) F. Aratani and K. Sanbonki: Tetsu-to-Hagané, 58 (1972), 1225.

11) O. Haida, S. Takeuchi, T. Nozaki, T. Emi and F. Sudo: Tetsu-to-Hagané, 68 (1982), 1744.

12) H. Ono, T. Masui and H. Mori: Tetsu-to-Hagané, 67 (1981), S934.

13) E. M. Levin, C. R. Robbins, and H. F. McMurdie: Phase Diagrams for Ceramists, Amer. Ceram. Soc., Ohio, (1964), 204. 